\title{
PReS-FINAL-2085: The p38-mediated rapid downregulation of cell surface gp130 expression impairs IL-6 signaling in the synovial fluid of juvenile idiopathic arthritis patients
}

\author{
N Honke*, K Ohl, A Wiener, N Wagner, S Wüller, K Tenbrock \\ From 20th Pediatric Rheumatology European Society (PReS) Congress \\ Ljubljana, Slovenia. 25-29 September 2013
}

\section{Introduction}

In patients with juvenile idiopathic arthritis (JIA) high levels of IL-6 are present in the serum and synovial fluid (SF). IL-6 signaling plays an important pro-inflammatory role but is restricted by regulatory mechanisms such as reducing the cell surface availability of the signaltransducing chain of the IL-6 receptor (gp130).

\section{Objectives}

The aim of this study was to determine whether the inflammatory environment in the arthritic joint has an impact on monocytic gp130 surface expression and the extent to which regulatory processes in the SF can be transferred to an in vitro model.

\section{Methods}

Flow cytometry and live-cell imaging were used to measure the cell surface expression and internalization of gp130. STAT3 phosphorylation was monitored by flow cytometry and western blotting.

\section{Results}

The level of cell surface gp130 expression on SF monocytes was reduced compared to peripheral blood (PB) monocytes from patients with JIA. This reduction could be reproduced by stimulating $\mathrm{PB}$ monocytes from healthy donors with SF and was dependent on p38 MAPK. The induction of $\mathrm{p} 38$ by IL- $1 \beta$ in PB monocytes interfered with IL-6 signaling due to the reduced cell surface expression of gp130.

Pediatrics, RWTH Aachen University, Universitätsklinikum, Aachen, Germany

\section{Conclusion}

The results suggest that $\mathrm{p} 38$-mediated pro-inflammatory stimuli induce the downregulation of gp130 on monocytes and thus restrict gp130-mediated signal transduction. This regulatory mechanism could be relevant in the inflamed joints of patients with JIA.

\section{Disclosure of interest}

None declared.

Published: 5 December 2013

doi:10.1186/1546-0096-11-S2-P97

Cite this article as: Honke et al:: PReS-FINAL-2085: The p38-mediated rapid downregulation of cell surface gp130 expression impairs IL-6 signaling in the synovial fluid of juvenile idiopathic arthritis patients. Pediatric Rheumatology 2013 11(Suppl 2):P97.

Submit your next manuscript to BioMed Central and take full advantage of:

- Convenient online submission

- Thorough peer review

- No space constraints or color figure charges

- Immediate publication on acceptance

- Inclusion in PubMed, CAS, Scopus and Google Scholar

- Research which is freely available for redistribution 